\title{
Enhanced Protease Inhibitor Expression in Plant Residues Slows Nitrogen Mineralization
}

\author{
K. Kumar,* C. J. Rosen, and M. P. Russelle
}

\begin{abstract}
Organic $\mathbf{N}$ mineralization by extracellular proteases affects inorganic $\mathrm{N}$ availability and loss. Soil $\mathrm{N}$ mineralization is slowed by addition of purified protease inhibitors. We hypothesized that elevated concentrations of protease inhibitors in plant residues would reduce soil and plant residue $\mathbf{N}$ mineralization. Isogenic controls and transgenic plants of Brassica (Brassica napus L.), Japonicum rice (Oryza sativa L.), and tobacco (Nicotiana tabaccum $L$.) showing enhanced wound-inducible protease inhibitor production were grown in a greenhouse, and leaves were mechanically wounded 3 d before shoot removal. Transgenic plants and their isogenic controls did not differ in $N$ concentration, $C / N$ ratio, or lignin concentration in shoot residues, but protease inhibitor concentration was 1.5 to 2.3 times greater in the transgenic lines. In laboratory incubations in a loamy sand soil, inorganic $\mathbf{N}$ in leachate from transgenic plants was significantly lower than isogenic controls for the first $30 \mathrm{~d}$ when the residues remained on the soil surface and were higher at one or more dates thereafter. When residues were mixed with soil, differences were observed only for Brassica. Cumulative $\mathbf{N}$ mineralization in static incubations of residues mixed with soil followed the order Brassica $>$ tobacco $>$ rice residues. In general, transgenic residues mineralized between 22 and $27 \%$ less $N$ than control plant residues in the first $30 \mathrm{~d}$, but no differences in soil $\mathbf{N}$ mineralization were detected. Thus, protease inhibitor concentration of plant residues should be included with measures of total $\mathrm{N}$ concentration, $\mathrm{C} / \mathrm{N}$ ratio, and lignin concentration to improve prediction and potentially management of short-term $\mathbf{N}$ mineralization from plant residues.
\end{abstract}

$\mathrm{M}$ OST N PRESENT in soil is in organic forms, primarily proteinaceous compounds. Soil acts as a sink for proteins from plants, animals, and microorganisms and also is an environment characterized by rapid protein hydrolysis under relatively wide ranges of soil temperature, water content, and pH (Hankin and Hill, 1978). Soil proteases originate from the same sources as proteins and are a mixture of heterogeneous, primarily extracellular, enzymes with different molecular weights, structures, cofactor requirements, and substrate specificities (Loll and Bollag, 1983). Proteolytic microorganisms may comprise 22 to $89 \%$ of the total soil microbial biomass (Hankin and Hill, 1978; Bach and Munch, 2000). Protein hydrolysis is a necessary first step in soil N mineralization and therefore regulates inorganic $\mathrm{N}$ availability to soil organisms and plants and to processes leading to $\mathrm{N}$ loss.

K. Kumar and C.J. Rosen; Dep. of Soil, Water, \& Climate, 1991 Upper Buford Circle, Room 439, Univ. of Minnesota, Saint Paul, MN 55108, USA; and M.P. Russelle, USDA-ARS Plant Sci. Res. Unit, 1991 Upper Buford Circle, Room 439, Univ. of Minnesota, Saint Paul, MN 55108, USA. K. Kumar, current address: Res. and Dev., Metropolitan Water Reclamation District of Greater Chicago, 6001 West Pershing Rd., Cicero, IL 60804-4112. Received 8 Sept. 2005. *Corresponding author (kuldip.kumar@mwrd.org).

Published in Agron. J. 98:514-521 (2006).

Nitrogen Management

doi:10.2134/agronj2005.0261

(c) American Society of Agronomy

677 S. Segoe Rd., Madison, WI 53711 USA
Most of the research on controlling the rate of $\mathrm{N}$ mineralization from crop residues, manures, and other organic materials that are added to the soil has concentrated on their management (e.g., degree of incorporation in the soil or timing of application) and their chemical characteristics (e.g., $\mathrm{C} / \mathrm{N}$ ratio, lignin concentration, or presence of polyphenols) (Kumar and Goh, 2000). These approaches have met with limited success, in part because of the difficulty in predicting $\mathrm{N}$ mineralization rates and extent. Furthermore, there have been no tactics to regulate soil organic matter $\mathrm{N}$ mineralization, which can be a significant source of $\mathrm{N}$ loss in annual grain and row crop systems (Keeney and DeLuca, 1993; David et al., 1997; Haynes, 1999). The ability to manage $\mathrm{N}$ mineralization would help reduce environmental contamination from $\mathrm{N}$ losses and improve $\mathrm{N}$ uptake efficiency by plants. This is where protease inhibitors may play a role.

Inhibitors of proteases are naturally present in plants, and their role as a defense mechanism against insects and disease organisms has been recognized (Geoffroy et al., 1990; Green and Ryan, 1992; Duan et al., 1996). In plants belonging to Gramineae, Leguminosae, Solanaceae, and other families, protease inhibitors are produced in response to pathogen attack, herbivory, or mechanical damage (Ryan, 1990; Green and Ryan, 1992). Protease inhibitors reduce the growth and survival of many insect herbivores when present in artificial diets and reduce both insect feeding rate and performance when expressed in transgenic plants (McManus et al., 1994; Cipollini and Bergelson, 2000). Transgenic modifications have enhanced protease inhibitor expression to develop insectresistant crop cultivars in several important crops. These plant protease inhibitors have specificities for animal and microbial proteases that are similar to the proteases in soils. Thus, these protease inhibitors may also affect the activity of soil proteases, which are responsible for early steps in soil $\mathrm{N}$ mineralization.

Of protease inhibitors, Loll and Bollag (1983, p. 367) stated that, "Little is known about the survival of these compounds in soil, but it is possible that they could affect proteolysis."; however, little has been published on this topic in the intervening two decades. Donegan et al. (1997) found no difference in $\mathrm{N}$ mineralization from leaves of tobacco engineered to express the tomato (Lycopersicum esculentum L.) protease inhibitor I ( $\mathrm{pJN} 3$ ) belonging to serine type inhibitors. More recently, Cowgill et al. (2002) concluded that expression of cysteine protease inhibitors in potato (Solanum tuberosum L.) residues did not alter residue decomposition in soil. In both studies with transgenic plants, dried tissues were used, which may have altered protease inhibitor activity. Neither study focused on $\mathrm{N}$ mineralization per se. We have found short-term reduction in soil $\mathrm{N}$ mineralization when purified protease inhibitors were added to soil and discovered that some 
protease inhibitors were more effective than others (Kumar et al., 2004). We hypothesized that addition of protease inhibitors to soil in organic amendments also would reduce the rate of $\mathrm{N}$ mineralization from both soil organic matter and plant residue. Although protease inhibitors are expressed in many plants, and expression can be enhanced by simple manipulation such as mechanical wounding, we used transgenic plants containing protease inhibitors and their isogenic lines as the model system in these experiments.

\section{MATERIALS AND METHODS}

\section{Transgenic Plants with Enhanced Protease Inhibitor and Isogenic Lines}

The transgenic and nontransformed parents used in our studies were (i) tobacco cultivar Xanthi, transformed line TR25 with Pin2-CAT gene; (ii) Brassica cultivar Wester, transformed line 108b, which is homozygous for Pin 2 from potato; and (iii) Japonicum rice cultivar TNG67, transformed homozygous transgenic line that harbors a modified potato Pin2 gene (batch 6-8-5, third generation seeds). All these transgenic plants show the enhanced expression of wound-inducible protease inhibitors belonging to serine class of protease inhibitors.

\section{Plant Propagation}

Plants were grown from seed in a greenhouse in 3.8-L round plastic pots containing Pro-Mix $\mathrm{BX}^{1}$ potting soil. Greenhouse photoperiod during experiments was controlled at $16 \mathrm{~h}$ of light and $8 \mathrm{~h}$ of dark using sodium vapor lamps. Mean daytime irradiance during these experiments was $800 \mu \mathrm{mol}$ photons $\mathrm{m}^{-2} \mathrm{~s}^{-1}$ photosynthetically active radiation. Temperature in the greenhouse averaged $27 \pm 4^{\circ} \mathrm{C}$ during the light period and $20 \pm 2^{\circ} \mathrm{C}$ during the dark period. Plants were watered daily with tap water and fertilized with $\mathrm{P}$ and $\mathrm{K}$ applied each at $50 \mathrm{mg} \mathrm{pot}^{-1}$ plus micronutrients in soluble fertilizer (MicroMax Granular, The Scotts Company, Marysville, OH). For each plant species, two plants were grown in each of 80 pots; one-half of these were planted with transgenic lines, and the other half were planted with isogenic control lines. One-half of each set of pots was fertilized with ${ }^{15} \mathrm{~N}$-enriched ammonium sulfate solution (total application of $200 \mathrm{mg} \mathrm{N}^{-1}$ at about 20 atom $\%{ }^{15} \mathrm{~N}$ ) and the other half with same amount of nonlabeled ammonium sulfate fertilizer $\left(0.366\right.$ atom $\left.\%{ }^{15} \mathrm{~N}\right)$. One plant species was grown at a time in a completely randomized fashion on two greenhouse benches, and pots were moved randomly within the benches every 3 to $4 \mathrm{~d}$. Plants receiving the ${ }^{15} \mathrm{~N}$ fertilizer were kept on one bench, and those with natural abundance fertilizer were kept on the other bench to minimize the risk of ${ }^{15} \mathrm{~N}$ movement to nonlabeled pots.

\section{Mechanical Wounding and Harvesting of Plant Materials}

Three days before harvesting approximately 6 -wk-old plants, at least $40 \%$ of the surface area of every leaf was wounded using sterilized needle-nosed forceps. Cipollini and Bergelson (2000) and Van Dam et al. (2001) have shown that protease inhibitor activity peaked at 3 to $4 \mathrm{~d}$ after wounding. The entire shoot tissue in each pot was harvested $3 \mathrm{~d}$ after wounding. The plants

\footnotetext{
${ }^{1}$ Mention of commercial products or specific companies by the University of Minnesota or the USDA-ARS does not constitute an endorsement or recommendations for use.
}

for each of the four groups, i.e., transgenic or isogenic control and with or without ${ }^{15} \mathrm{~N}$, were separately crushed in separate food processors. Six subsamples of plants from each group were placed in 1.7-mL microfuge tubes, flash-frozen in liquid $\mathrm{N}_{2}$, and stored at $-20^{\circ} \mathrm{C}$ until analysis or kept on ice and analyzed for protease inhibitor activity within $4 \mathrm{~h}$. Four preweighed subsamples of freshly crushed plant materials from each group were dried at $55^{\circ} \mathrm{C}$ for 48 to $72 \mathrm{~h}$ in forced-air ovens to determine moisture content and were ground to a powder in a Tecator mill for subsequent chemical analysis. Freshly crushed plant materials were used in the laboratory incubation studies as discussed below and hereafter are referred as transgenic residues and isogenic control residues.

\section{Incubation Procedures}

Two laboratory incubation experiments were conducted using Hubbard loamy sand soil (sandy, mixed, frigid Entic Hapludolls) collected from surface 0 to $15 \mathrm{~cm}$ near Becker, MN. The soil was comprised of $78 \%$ sand and $10 \%$ clay as determined by the hydrometer method (Bouyoucos, 1951) and contained $13 \mathrm{~g} \mathrm{~kg}^{-1}$ organic $\mathrm{C}$ as determined by dry combustion method (Nelson and Sommers, 1982). Soil water content retained at a pressure potential of $10 \mathrm{kPa}$ (equivalent to field capacity) was $15 \%(\mathrm{w} / \mathrm{w})$ as determined by the pressure plate apparatus (Klute, 1986). Soil pH was 6.5 as determined in a 1:1 soil:water mixture after stirring for $2 \mathrm{~min}$ (McLean, 1982). Bray $\mathrm{P}$ was $42 \mathrm{mg} \mathrm{kg}^{-1}$, and ammonium acetate extractable $\mathrm{K}$ was $135 \mathrm{mg} \mathrm{kg}^{-1}$ soil. Soil inorganic $\mathrm{N}\left(\mathrm{NH}_{4}-\mathrm{N}\right.$ and $\left.\mathrm{NO}_{3}-\mathrm{N}\right)$ was extracted with $2 \mathrm{M} \mathrm{KCl}$ from field moist soil samples before starting the incubations and was measured by conductimetric methods (Carlson et al., 1990). Field moist soil was mixed and passed through a 2-mm sieve. Before the incubation experiments began, the soil was preconditioned at a constant temperature of $25^{\circ} \mathrm{C}$ and adjusted to field capacity water content over a 2 -wk period.

\section{Experiment 1}

This $\mathrm{N}$ mineralization study was conducted in leaching tubes (30-cm length, 5-cm diam.), in which non- ${ }^{15} \mathrm{~N}$-labeled transgenic and isogenic control plant residues (15 $\mathrm{g}$ fresh weight) were either left on the surface of soil (100 g oven-dry basis) or mixed with soil and then added to the leaching tubes. Soil in the leaching tubes was supported by a layer of acid-washed quartz sand on a layer of glass wool. A thin glass wool pad was placed on the surface of the mixed soil and plant material to protect it from dispersion during water addition.

The experiment consisted of six replications of the following five treatments:

1. transgenic plant residues on the soil surface;

2. isogenic control plant residues on the soil surface;

3. transgenic plant residues mixed with the soil;

4. isogenic control plant residues mixed with the soil; and

5. soil only (background control).

The 30 leaching tubes were mounted randomly on stands and incubated at $25^{\circ} \mathrm{C}$ for $100 \mathrm{~d}$. The soil plus residue mixture was leached $1 \mathrm{~d}$ after treatment with $100 \mathrm{~mL}$ of deionized water to remove the soil $\mathrm{N}$ mineralized during preconditioning and was leached periodically thereafter. The leaching tubes were capped with a perforated lid (5-mm diam.) to restrict evaporation but allow aeration. Moisture content was maintained every $5 \mathrm{~d}$ by adding deionized water as necessary after weighing the tubes. The volume of the leachate collected from each leaching tube was recorded, made up to final volume of $100 \mathrm{~mL}$, and analyzed for $\mathrm{NH}_{4}-\mathrm{N}$ and $\mathrm{NO}_{3}-\mathrm{N}$ using the con- 
ductimetric procedure of Carlson et al. (1990). This experiment was repeated with the other two plant species separately.

\section{Experiment 2}

Concurrently with Experiment 1, a static incubation experiment was conducted in which ${ }^{15} \mathrm{~N}$-labeled transgenic plant residues and isogenic control residues were mixed with preconditioned soil (200 g of dry weight) at field capacity water content at the same rate of application as in Experiment $1(15 \mathrm{~g}$ of fresh weight per $100 \mathrm{~g}$ of soil) in 500-mL plastic containers. Treatments were replicated four times. These containers were covered with screw-top lids having two holes of 5-mm diam. to facilitate aeration and were incubated at $25^{\circ} \mathrm{C}$ for $8 \mathrm{wk}$. The containers were weighed every 4 to $5 \mathrm{~d}$, and evaporative losses were replaced using deionized water. After 4, 6, and 8 wk, soil samples were extracted with $2 \mathrm{M} \mathrm{KCl}$ and analyzed for inorganic $\mathrm{N}\left(\mathrm{NH}_{4}+\mathrm{NO}_{3}\right)$ using conductimetric methods (Carlson et al., 1990). The ${ }^{15} \mathrm{~N}$ enrichment of inorganic $\mathrm{N}$ was determined using the modified diffusion method of Brooks et al. (1989) with appropriate standards as suggested by Lory and Russelle (1994). The filter papers with diffused ${ }^{15} \mathrm{~N}$ were dried over sulfuric acid in a desiccator and transferred to tin capsules, which were analyzed for ${ }^{15} \mathrm{~N}$ concentration by the Stable Isotope Laboratory at the University of California, Davis.

\section{Characteristics of Transgenic and Isogenic Control Plant Residues}

\section{Extraction of Soluble Proteins}

The procedure outlined by Cipollini and Bergelson (2001) was used to extract soluble proteins from leaf tissues of transgenic and isogenic control plants. Briefly, leaf tissue samples were further crushed and ground in microfuge tubes with a Teflon minipestle. A $150-\mu \mathrm{L}$ aliquot of ice-cold $1 \mathrm{~m} M \mathrm{HCl}$ was placed in each tube and vortexed for $30 \mathrm{~s}$. After centrifugation at $12000 \mathrm{~g}$ for $10 \mathrm{~min}$ at $4^{\circ} \mathrm{C}$, the clear supernatant was transferred to new tubes and kept on ice for analysis of protease inhibitor activity and soluble protein quantification.

\section{Soluble Protein Content}

Soluble protein contents of each tissue extracts were quantified by the method of Bradford (1976) by using the Bio-Rad protein dye reagent.

\section{Protease Inhibitor Activity}

Protease inhibitor activity of the extracts was analyzed using a radial diffusion assay with a trypsin-containing agar (Cipollini and Bergelson, 2000). The procedure involved cooling of $100 \mathrm{~mL}$ of melted agar (Bacto-Agar, Difco, Detroit, MI) solution ( $18 \% \mathrm{w} / \mathrm{v}$ in $100 \mathrm{mM}$ Tris $\mathrm{Cl}$ buffer, $\mathrm{pH} 7.6)$ to $55^{\circ} \mathrm{C}$ and mixing it with a solution of bovine trypsin (Sigma Chemical Co., St. Louis, MO) to a final concentration of $1 \mu \mathrm{g} \mathrm{mL}^{-1}$ in the agar. Immediately after adding the enzyme, the melted solution was poured into a $24-$ by $24-\mathrm{cm}$ square plastic bioassay dish (Nunc, Denmark) and allowed to solidify at $4^{\circ} \mathrm{C}$ for $4 \mathrm{~h}$. Holes $4 \mathrm{~mm}$ in diameter were punched in the agar gel plate to accommodate each extracted sample. Sample extracts $(28 \mu \mathrm{L})$ were introduced into wells randomly throughout the gel and were allowed to diffuse at $4{ }^{\circ} \mathrm{C}$ for $24 \mathrm{~h}$. Following incubation, the gel was rinsed with $100 \mathrm{~m} M$ Tris $\mathrm{Cl}, \mathrm{pH} 7.6$ buffer containing $10 \mathrm{~m} M$ $\mathrm{CaCl}_{2}$, for $2 \mathrm{~min}$. After rinsing, a solution containing $48 \mathrm{mg}$ of Fast Blue B Salt ( $O$-dianisidine) in $90 \mathrm{~mL}$ of $100 \mathrm{~m} M$ Tris $\mathrm{Cl}, \mathrm{pH}$ 7.6 , at $37^{\circ} \mathrm{C}$ was mixed with $24 \mathrm{mg} N$-acetyl-DL-phenylalanine- naphthyl ester in $10 \mathrm{~mL}$ of $N, N$-dimethylformamide and immediately poured onto the gel. The gel was then incubated at $37^{\circ} \mathrm{C}$ for $30 \mathrm{~min}$ and rinsed four times with tap water. Following this step, the zone with protease inhibitor activity around each well remained clear, but the rest of the gel stained a bright pink purple. Protease inhibitor activity was quantified by measuring the diameter of the clear zones around each well using a digital vernier caliper. Samples were compared with a standard curve made with purified soybean trypsin inhibitor in $1 \mathrm{~m} M \mathrm{HCl}$ run in the same gel with the sample extracts. Protease inhibitor content of each extract was expressed as micrograms of trypsin inhibitor per milligram of extracted protein.

\section{Total Nitrogen and Carbon Content}

A subsample of each plant shoot after drying was finely ground using a Tecator mill and sent to the Stable Isotope Laboratory at the University of California, Davis, for ${ }^{15} \mathrm{~N}$ analysis. The analysis was performed using a commercial continuous flow $\mathrm{C}-\mathrm{N}$ analyzer equipped with online sample combustion, connected to an isotope ratio mass spectrometer. Dry combustion was used to determine total $\mathrm{N}$ and $\mathrm{C}$ on separate dried plant samples (Nelson and Sommers, 1982).

\section{Lignin Content}

Klason lignin concentration was determined by a two-stage sulfuric acid hydrolysis (Theander et al., 1995). Whole-plant samples were treated with $\alpha$-amylase and amyloglucosidase in $0.1 \mathrm{M}$ acetate buffer ( $\mathrm{pH} 5$ ) to hydrolyze starch before addition of ethanol to achieve a final concentration of $80 \%(\mathrm{v} / \mathrm{v})$. After centrifugation and discarding of the supernatant, the alcohol insoluble residue was subjected to a $12 M$ sulfuric acid treatment for $1 \mathrm{~h}$ at $39^{\circ} \mathrm{C}$ to solubilize cell wall polysaccharides. The sample and sulfuric acid solution were then diluted with nano-pure water to a concentration of $0.4 M$ sulfuric acid and placed in an autoclave for $1 \mathrm{~h}$ at $117^{\circ} \mathrm{C}$ to hydrolyze the cell wall polysaccharides. Insoluble Klason lignin residues were collected by filtration through a glass fiber filter in a Gooch crucible after the acid hydrolysis and corrected for ash content by combustion.

\section{Calculations}

Percentage $\mathrm{N}$ mineralized from leaching tube experiment was calculated with the following equation:

$$
\begin{aligned}
& {[\% \mathrm{~N} \text { mineralized }=} \\
& \left.\frac{\sum_{1}^{n}\left(N_{\min } \text { from residue-amended soil }-N_{\min } \text { from control soil }\right)}{\text { Residue } \mathrm{N}} \times 100\right]
\end{aligned}
$$

where $n$ is the number of leaching events and $N_{\min }$ is the milligrams of $\mathrm{N}$ contained in the leachate at each event.

Percentage $\mathrm{N}$ mineralized from the ${ }^{15} \mathrm{~N}$-labeled residue experiment was calculated using the isotopic calculations provided in Hauck (1982).

\section{Statistical Analysis}

Characteristics of transgenic and isogenic control residues were compared using Tukey's Studentized Range Test. The data on $\mathrm{N}$ mineralization were tested for differences between transgenic and isogenic control residues separately for each leaching date and method using analysis of variance (ANOVA) procedures in SAS (SAS Inst., 1989). Means were compared using Fisher's Protected Least Significant Difference Test when 
the $F$ test in the ANOVA had a probability $P \leq 0.05$. Because each plant species was evaluated in separate runs of each experiment, we could not directly compare effects due to species.

\section{RESULTS}

\section{Characteristics of Plant Residues}

There were no statistical differences between transgenic and isogenic control plant shoots within any of the three plant species in terms of $\mathrm{N}$ concentration, lignin concentration, and $\mathrm{C} / \mathrm{N}$ ratio (Table 1 ). The $\mathrm{N}$ concentration was the least for Brassica and most for tobacco. However, $\mathrm{C} / \mathrm{N}$ ratio and lignin concentration followed the order Brassica $<$ tobacco $<$ rice (Table 1). Protease inhibitor activity of transgenic plants was significantly greater than their isogenic controls (Table 1). Maximum protease inhibitor activity of $28 \mathrm{mg} \mathrm{g}^{-1}$ protein was found in transgenic Brassica shoots, which was 2.3 times that found in the isogenic control line (Table 1).

\section{Nitrogen Mineralization}

\section{Leaching Tube Experiments}

Brassica. Nitrogen release followed a similar trend irrespective of whether the residues were placed on the soil surface or mixed with the soil. The concentrations of inorganic $\mathrm{N}$ in the leachate were significantly less in the transgenic plant residues compared with the isogenic plant residues for the first $30 \mathrm{~d}$ of incubation, but the reverse was observed as the incubation proceeded (Fig. 1a and 1b). A significantly greater cumulative proportion of $\mathrm{N}$ was mineralized from isogenic control plant residues than from transgenic Brassica residues, and differences were more pronounced when residues were left on the soil surface (Fig. 1b). When plant residues were mixed with soil, the differences in percentage $\mathrm{N}$ mineralized were significant only as long as $80 \mathrm{~d}$ (Fig. 1a). By the end of $100 \mathrm{~d}$ of incubation, there was no difference in total $\mathrm{N}$ mineralization between transgenic Brassica and the isogenic control residues when mixed with soil (Fig. 1a), but when residues were left on the soil, $\mathrm{N}$ mineralization was $24 \%$ lower for transgenic residues than the isogenic control residues at $100 \mathrm{~d}$ (Fig. 1b).

Table 1. Characteristics of transgenic and isogenic control plant residues.

\begin{tabular}{|c|c|c|c|c|}
\hline Plant residue source & $\mathbf{N}$ conc. & $\begin{array}{r}\mathrm{C} / \mathrm{N} \\
\text { ratio }\end{array}$ & $\begin{array}{c}\text { Klasson } \\
\text { lignin }\end{array}$ & $\begin{array}{l}\text { Protease } \\
\text { inhibitor }\end{array}$ \\
\hline & $\mathbf{m g ~ \mathbf { g } ^ { - 1 }}$ & & $\mathbf{m g} \mathbf{g}^{-1}$ & $\mathrm{mg} \mathrm{g}^{-1}$ protein \\
\hline \multicolumn{5}{|l|}{ Brassica } \\
\hline Isogenic control & 20.4 & 17.5 & 5.4 & $11.9 \mathrm{~b} \dagger$ \\
\hline PI-transgenic $\ddagger$ & 20.6 & 17.1 & 5.3 & $28.3 \mathrm{a}$ \\
\hline \multicolumn{5}{|l|}{ Rice } \\
\hline Isogenic control & 22.2 & 22.3 & 12.2 & $10.1 \mathrm{~b}$ \\
\hline PI-transgenic & 22.0 & 22.1 & 11.0 & 20.4 a \\
\hline \multicolumn{5}{|l|}{ Tobacco } \\
\hline Isogenic control & 23.6 & 19.7 & 10.8 & $16.2 \mathrm{~b}$ \\
\hline PI-transgenic & 24.0 & 19.2 & 10.8 & 24.3 a \\
\hline
\end{tabular}

$\uparrow$ Means followed by different letters in each column for a particular type of plant residue are significantly different at $P \leq 0.05$ according to Tukey's Studentized Range Test. Where no letters are present, the differences are not significant at $P \leq 0.05$.

$\uparrow$ PI, protease inhibitor.
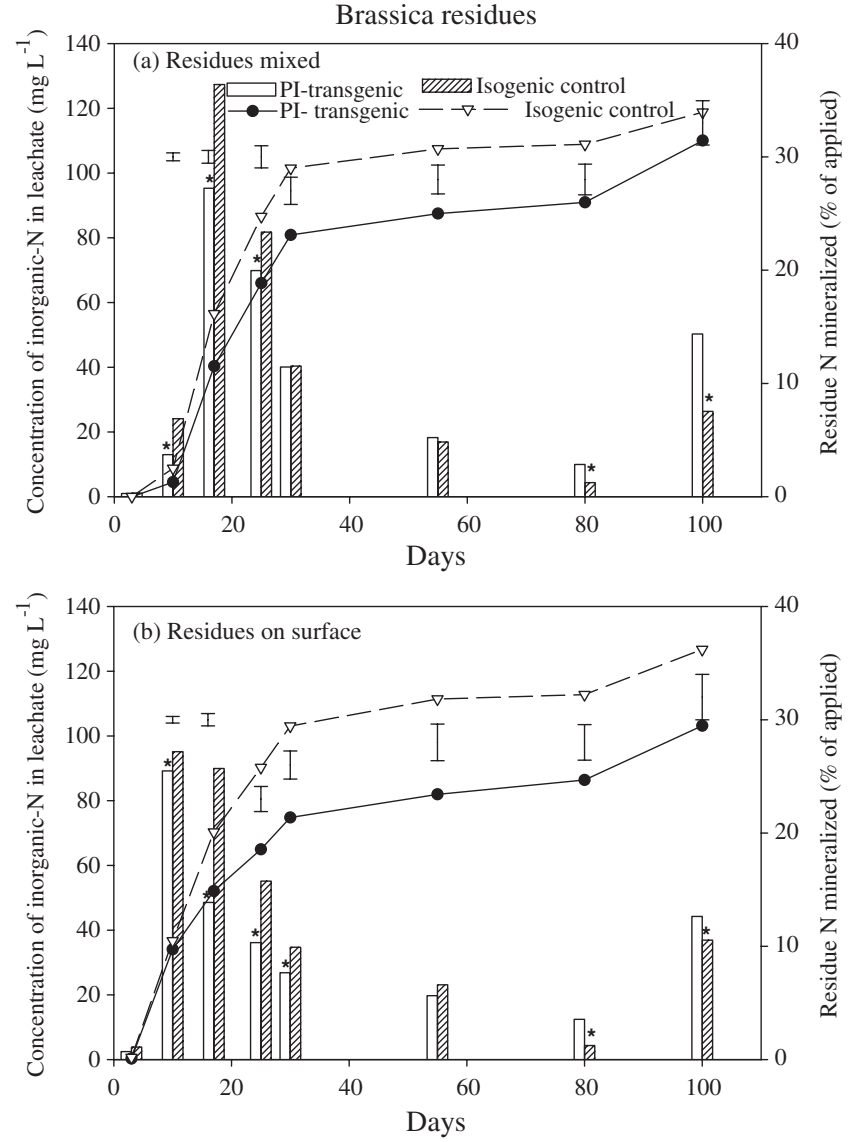

Fig. 1. Concentration of inorganic $\mathbf{N}$ in leachate during periodic leaching events (bars) and percentage $\mathbf{N}$ mineralized from transgenic Brassica and isogenic control plant residues (lines) for (a) residues mixed with soil and (b) residues on soil surface. Asterisks represent significant differences $(P \leq 0.05)$ in inorganic $N$ concentration in leachate between transgenic and isogenic control residues. Bars represent the least significant difference $(P \leq 0.05)$ in cumulative residue $N$ mineralized between transgenic Brassica and isogenic control plant residues. PI, protease inhibitor.

Rice. When rice residues were mixed with soil, there were no differences either in incremental or in cumulative $\mathrm{N}$ mineralization (Fig. 2a). However, for surfaceapplied residues, concentrations of inorganic $\mathrm{N}$ in leachate from transgenic plant residues were significantly less than $\mathrm{N}$ in leachate from isogenic control plant residues for the first $30 \mathrm{~d}$ (Fig. 2b). Beginning with the leaching at $80 \mathrm{~d}$ (representing the period from 58 to $80 \mathrm{~d}$ ), concentrations of inorganic $\mathrm{N}$ in leachate from the transgenic plant residue treatment exceeded those of the isogenic plant residues (Fig. 2b). Cumulative $\mathrm{N}$ mineralization over $100 \mathrm{~d}$ from transgenic rice residues was $15 \%$ less than $\mathrm{N}$ mineralized from isogenic control residues when residues were surface-applied.

Tobacco. Similar to results with rice residues, there were no differences in $\mathrm{N}$ mineralization when transgenic and isogenic control tobacco shoot tissue was mixed with soil, except in the second week of incubation (Fig. 3a). However, when residues were placed on the soil surface, significantly less inorganic $\mathrm{N}$ was leached from tubes containing transgenic residues than isogenic control residues for the first $30 \mathrm{~d}$. Thereafter, $\mathrm{N}$ min- 

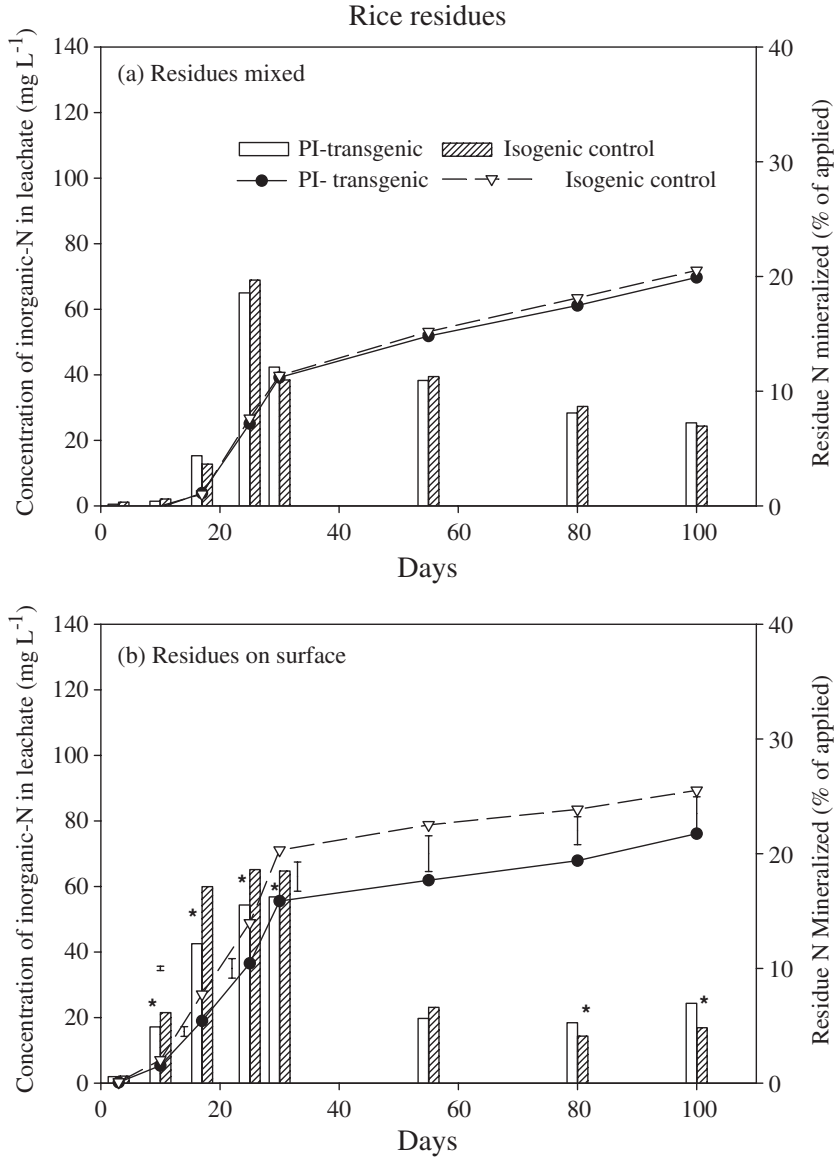

Fig. 2. Concentration of inorganic $\mathrm{N}$ in leachate during periodic leaching events (bars) and percentage $\mathbf{N}$ mineralized from transgenic rice and isogenic control plant residues (lines) for (a) residues mixed with soil and (b) residues on soil surface. Asterisks represent significant differences $(P \leq 0.05)$ in inorganic $N$ concentration in leachate between transgenic and isogenic control residues. Bars represent the least significant difference $(P \leq 0.05)$ in cumulative residue $\mathbf{N}$ mineralized between transgenic rice and isogenic control plant residues. PI, protease inhibitor.

eralization tended to be greater for transgenic residues (Fig. 3b). Differences in cumulative $\mathrm{N}$ mineralization remained significant for most of the incubation period, with transgenic tobacco plant residues mineralizing about $13 \%$ less $\mathrm{N}$ than the isogenic control (Fig. 3b). However, by $100 \mathrm{~d}$, differences in cumulative $\mathrm{N}$ mineralization between transgenic and isogenic control tobacco residues disappeared.

\section{Nitrogen Mineralized from ${ }^{15} \mathbf{N}$-Labeled Residues}

The $\mathrm{N}$ mineralization from ${ }^{15} \mathrm{~N}$-labeled residues during static incubation followed the order Brassica $>$ tobacco $>$ rice residues when mixed with the soil (Table 2). In general, less $\mathrm{N}$ was mineralized from transgenic residues of Brassica, rice, and tobacco than from their isogenic controls for the first 30 to $45 \mathrm{~d}$. At $30 \mathrm{~d}$ of incubation, for example, transgenic residues of these three species mineralized between 22 and $27 \%$ less $\mathrm{N}$ than their isogenic controls. Thereafter, differences in cumulative $\mathrm{N}$ mineralization generally were not detected.
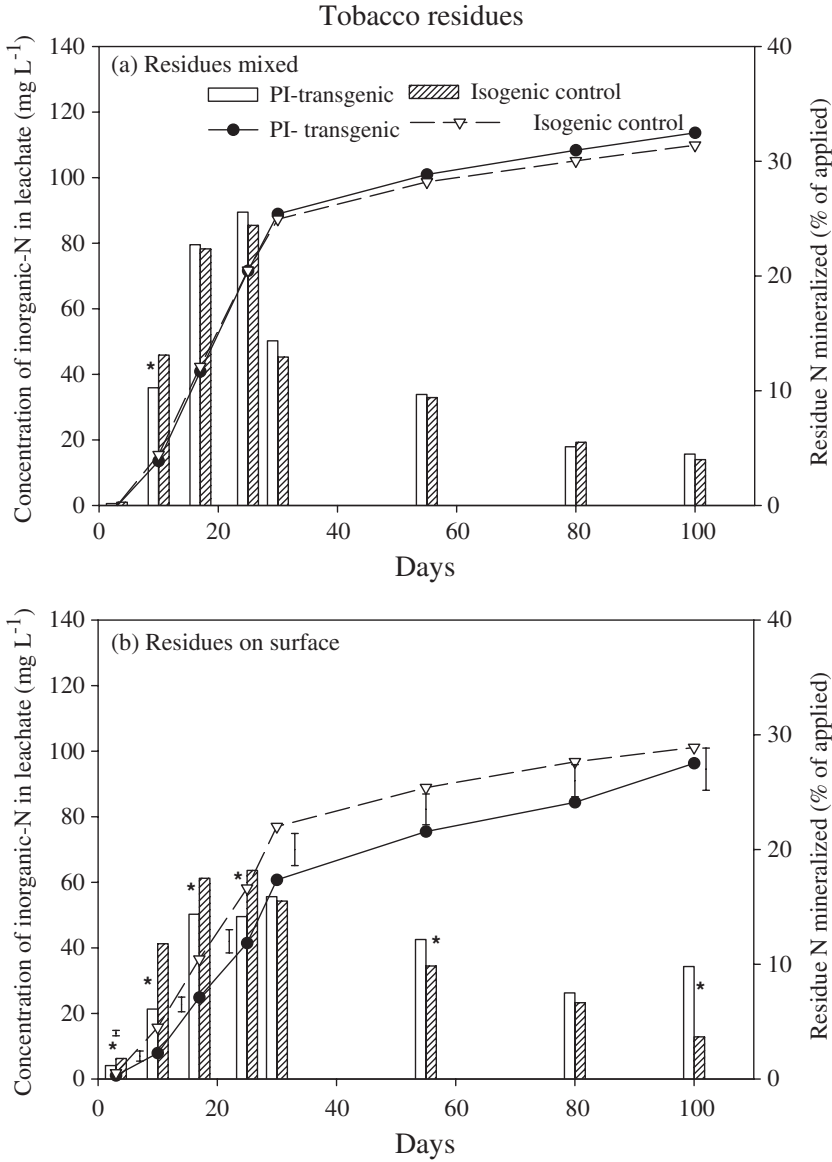

Fig. 3. Concentration of inorganic $N$ in leachate during periodic leaching events (bars) and percentage $\mathbf{N}$ mineralized from transgenic tobacco and isogenic control plant residues (lines) for (a) residues mixed with soil and (b) residues on soil surface. Asterisks represent significant differences $(P \leq 0.05)$ in inorganic $N$ concentration in leachate between transgenic and isogenic control residues. Bars represent the least significant difference $(P \leq 0.05)$ in cumulative residue $\mathbf{N}$ mineralized between transgenic tobacco and isogenic control plant residues. PI, protease inhibitor.

In contrast to mineralization of added plant residues, mineralization of soil $\mathrm{N}$ did not differ between transgenic and isogenic control plant residue treatments. Mean soil

Table 2. Percentage of $\mathrm{N}$ mineralized from ${ }^{15} \mathrm{~N}$-labeled transgenic and isogenic control plant residues.

\begin{tabular}{|c|c|c|c|c|c|c|}
\hline \multirow[b]{2}{*}{ Plant residue source } & \multicolumn{6}{|c|}{ Days of incubation } \\
\hline & 7 & 15 & 30 & 45 & 60 & 90 \\
\hline & & & $\operatorname{lant} \mathbf{N}$ a & lied, \% & & 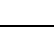 \\
\hline \multicolumn{7}{|l|}{ Brassica } \\
\hline Isogenic control & $6.2 \mathrm{a} t$ & $8.0 \mathrm{a}$ & 11.3 a & 18.8 a & 26.2 & 39.1 \\
\hline PI-transgenic§ & $3.8 \mathrm{~b}$ & $5.6 \mathrm{~b}$ & $8.8 \mathrm{~b}$ & $15.8 \mathrm{~b} \neq$ & 25.8 & 40.9 \\
\hline \multicolumn{7}{|l|}{ Rice } \\
\hline Isogenic control & 0.1 & $4.0 \mathrm{a}$ & $8.3 \mathrm{a}$ & 14.8 & 19.7 & 28.3 \\
\hline PI-transgenic & 0.1 & $2.0 \mathrm{~b}$ & $6.3 \mathrm{~b}$ & 15.2 & 21.1 & 27.7 \\
\hline \multicolumn{7}{|l|}{ Tobacco } \\
\hline Isogenic control & $2.3 \mathrm{a}$ & $8.8 \mathrm{a}$ & $18.5 \mathrm{a}$ & 23.7 & 28.6 & 37.0 \\
\hline PI-transgenic & $1.3 \mathrm{~b}$ & $5.3 \mathrm{~b}$ & $13.4 \mathrm{~b}$ & 23.0 & 30.1 & 36.3 \\
\hline
\end{tabular}

$\dagger$ Means followed by different letters in each column for a particular plant residue are significantly different at $P \leq 0.05$ by an ANOVA protected LSD test. Where no letters are present, the differences are not significant at $P \leq 0.05$.

$\$$ Significant at $P \leq \mathbf{0 . 1 0}$.

$\S \mathrm{PI}$, protease inhibitor. 
$\mathrm{N}$ mineralization from Brassica, tobacco, and rice residue treatments during the $100-\mathrm{d}$ incubation was 69,62 , and $59 \mathrm{mg} \mathrm{kg}^{-1}$ soil, respectively.

Differences between transgenic and isogenic control treatments were detected during the first $30 \mathrm{~d}$ of incubation in all three species in this ${ }^{15} \mathrm{~N}$-labeling experiment (Table 2) but were not detected without the use of the isotope in two of the three species when residues were mixed with the soil (Fig. 2a and 3a).

\section{Relationship between Nitrogen Mineralized and Residue Characteristics}

The data on percentage $\mathrm{N}$ mineralized from surfaceapplied residues from the leaching tube experiment at 30 and $100 \mathrm{~d}$ of incubation and at $30 \mathrm{~d}$ from ${ }^{15} \mathrm{~N}$-labeled residue experiment were regressed against residue characteristics (Table 3). For surface-applied residues, the models with (a) $\mathrm{C} / \mathrm{N}$ ratio and protease inhibitor concentration; (b) $\mathrm{N}$ concentration, lignin concentration, and protease inhibitor concentration; and (c) $\mathrm{C} / \mathrm{N}$ ratio, lignin concentration, and protease inhibitor concentration (Models 8, 9, 10, 18, 19, and 20) performed better in explaining the variability in $\mathrm{N}$ mineralization at 30 and $100 \mathrm{~d}$ of incubation than models with $\mathrm{N}$ concentration or $\mathrm{C} / \mathrm{N}$ ratio alone or in combination with lignin concentration (Table 3). However, when residues were mixed as in

Table 3. Coefficients for multiple regression of percentage $\mathbf{N}$ mineralized from plant residues and chemical characteristics of transgenic and isogenic control plant residues.

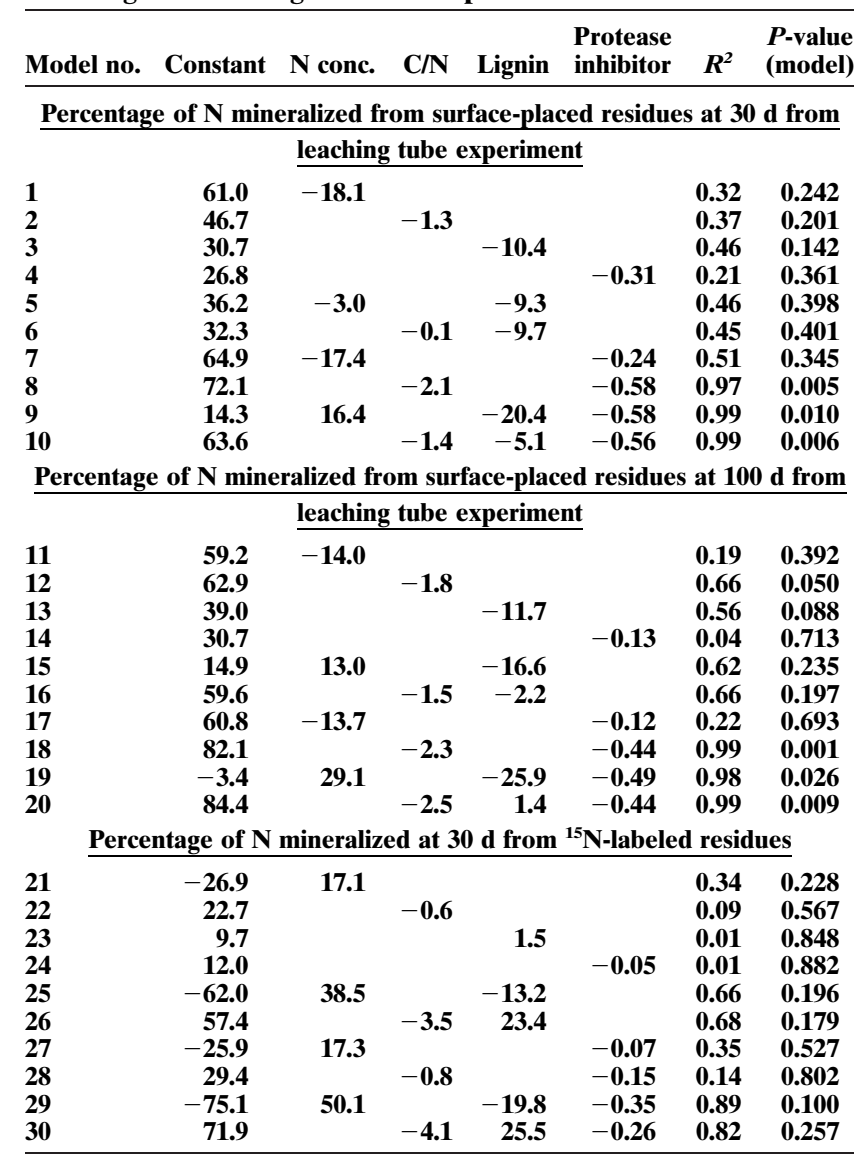

the ${ }^{15} \mathrm{~N}$-labeling experiment, Model 29 with $\mathrm{N}$ concentration, lignin concentration, and protease inhibitor concentration performed better in explaining the variability in $\mathrm{N}$ mineralized at $30 \mathrm{~d}$ of incubation (Table 3 ).

\section{DISCUSSION}

This is the first time, to our knowledge, that a comparison in $\mathrm{N}$ mineralization has been made for isogenic lines of plant species expressing different protease inhibitor activity but which do not differ in $\mathrm{N}$ concentration, $\mathrm{C} / \mathrm{N}$ ratio, or lignin concentration. These are the three major characteristics most often used to explain the $\mathrm{C}$ and $\mathrm{N}$ mineralization from crop residues (Kumar and Goh, 2000, 2003). Earlier studies on decomposition of transgenic plants used plants that differed in quality relative to parent plants. For example, Donegan et al. (1997) used transgenic and parent tobacco plants that differed in C concentration, and Flores et al. (2005) used transgenic $\mathrm{Bt}$ and parent corn (Zea mays L.) plants that differed in lignin concentration.

Protease inhibitor concentration in transgenic plant residues used in our experiments was significantly higher than in isogenic control plants (Table 1). These transgenic plants have been modified to express higher protease inhibitor activity to increase their resistance to insect pests (Ryan, 1981; Duan et al., 1996; Cipollini and Bergelson, 2000, 2001; Van Dam et al., 2001). The concentrations of protease inhibitor present in residues used in our experiments were similar to those reported earlier (Cipollini and Bergelson, 2001; Van Dam et al., 2001).

Because protease enzymes play an important role in the $\mathrm{N}$ mineralization process, we expected that the presence of protease inhibitors would reduce $\mathrm{N}$ mineralization in soil. Our earlier studies (Kumar et al., 2004) showed that soil $\mathrm{N}$ mineralization was affected when soils were amended directly with specific inhibitors of different proteases. In the experiments reported here, we found that enhanced quantities of protease inhibitors in transgenic plant residues reduced $\mathrm{N}$ mineralization from plant residues (Fig. 2 and 3 and Table 2), especially when residues remained on the soil surface. We detected no difference in $\mathrm{N}$ mineralization from soil organic matter when we used ${ }^{15} \mathrm{~N}$-labeled plant residues as a means of tracing the source of $\mathrm{N}$ mineralized. Thus, it appears that doubling the inherent level of protease activity level in plants temporarily slowed the rapid mineralization of $\mathrm{N}$ from fresh plant residues but did not affect mineralization of the existing soil organic matter. This suggests that selection and management of winter cover crops to increase protease inhibitor concentrations (for example, employing mechanical damage a few days before terminating the stand) may result in improved control of $\mathrm{N}$ mineralization from these residues. Optimizing this strategy for managing organic $\mathrm{N}$ mineralization might have the largest impact on water quality protection on permeable soils.

This conclusion can be augmented by the realization that the type of protease inhibitor has a large influence on $\mathrm{N}$ mineralization (Kumar et al., 2004). These plants have increased amounts only of serine protease inhibi- 
tors, which are specific inhibitors of trypsin and chymotrypsin protease enzymes. However, in soil, there are other types of protease enzymes present, such as cysteine, aspartic, and metalloproteases. Our earlier work showed greater reduction in soil $\mathrm{N}$ mineralization with addition of protease inhibitor leupeptin that inhibits serine + cysteine or a complete inhibitor that inhibits serine + cycteine + aspartic + metalloproteases than with addition of aprotinin that inhibits only serine type proteases (Kumar et al., 2004). Thus, for higher and longer-term effects with transgenic plants, it will be necessary to engineer increased expression of two or more types of protease inhibitors with specificities against different classes of protease enzymes present in soil.

Why were effects of protease inhibitor activity smaller when plant residues were mixed with the soil? Increased microbial activity resulting from residue mixing as compared with surface-applied residues (Harper and Lynch, 1981; Kumar and Goh, 2000) might have resulted in greater proteolytic enzyme activity. Alternatively, concentrations of protease inhibitors may decrease rapidly due to faster decomposition when residues are mixed with soil. This may be the reason that when residues were mixed, we observed differences only in case of Brassica residues that had relatively greater protease inhibitor activity compared with rice or tobacco residues. Donegan et al. (1997) found that protease inhibitor concentration of plant residues was reduced by about $50 \%$ within $14 \mathrm{~d}$ after incorporation in soil and only $0.3 \%$ was measured after $35 \mathrm{~d}$. Those researchers also found no differences in mineralization of soil $\mathrm{N}$ when transgenic or isogenic plant residues were mixed with the soil. We suspect that protease inhibitor activity in transgenic plant residues used in our experiments was not sufficiently high and/or was too enzymatically specific to affect the proteolytic activity outside the plant tissues.

Endogenous plant protease inhibitors play a significant role in $\mathrm{N}$ mineralization, at least over time periods of several weeks (Table 3). Including protease inhibitor concentration in models that had contained only $\mathrm{C} / \mathrm{N}$ ratio, $\mathrm{N}$ concentration, or lignin concentration significantly improved the prediction of $\mathrm{N}$ mineralization. Because protease enzymes play an important role in $\mathrm{N}$ cycling, the amount (and probably the types) of protease inhibitors in both natural and genetically modified plants should be considered in characterizing residue quality in addition to $\mathrm{N}$ concentration, $\mathrm{C} / \mathrm{N}$ ratio, lignin concentration, etc., commonly used in earlier studies (Whitmore and Handayanto, 1997; Trinsoutrot et al., 2000). Elevated concentrations of protease inhibitors can be found not only in specialized transgenic plants, but also in nonmodified lines of plants like soybean [Glycine max (L.) Merr.], cowpea (Vigna radiata L.), and potato (Koiwa et al., 1997).

\section{CONCLUSIONS}

Our results indicate that concentration of protease inhibitors in plant residues is an additional residue quality parameter that should be considered when predicting $\mathrm{N}$ cycling from plant residues. In addition, we have shown in this model system that there is potential for using protease inhibitors to better synchronize $\mathrm{N}$ mineralization with crop $\mathrm{N}$ demand and to reduce $\mathrm{N}$ losses in annual crop rotations. More information is needed about the amounts and types of protease inhibitors contained in plant tissue of crops and major weed species, the effect of management (e.g., mechanical wounding) on concentrations of endogenous protease inhibitors before stand termination, and the short- and long-term effects of plant residue protease inhibitors on $\mathrm{N}$ mineralization.

\section{ACKNOWLEDGMENTS}

The authors thank Dr. Ray Wu of Cornell University, Dr. Joy Bergelson of University of Chicago, and Dr. Robert Thornburg of Iowa State University for providing transgenic and parent seeds of rice, Brassica, and tobacco, respectively. We also thank Dr. H.-J.G. Jung, USDA-ARS, Saint Paul, for lignin analysis and Mathew McNearney for technical help in the laboratory. This project was supported by National Research Initiative Competitive Grant no. 2002-35107-12436 from the USDA Cooperative State Research, Education, and Extension Service.

\section{REFERENCES}

Bach, H.-J., and J.C. Munch. 2000. Identification of bacterial sources of soil peptidases. Biol. Fertil. Soils 31:219-224.

Bouyoucos, G.J. 1951. An improved type of soil hydrometer. Soil Sci. 76:377-378.

Bradford, M.M. 1976. A rapid and sensitive method for the quantification of microgram quantities of protein utilizing the principle of protein-dye binding. Anal. Biochem. 72:248-254.

Brooks, P.D., J.M. Stark, B.B. McInteer, and T. Preston. 1989. A diffusion method to prepare soil extracts for automated nitrogen-15 analysis. Soil Sci. Soc. Am. J. 53:1707-1711.

Carlson, R.M., R.I. Cabrera, J.L. Paul, J. Quaick, and R.Y. Evans. 1990. Rapid direct determination of ammonium and nitrate in soil and plant tissue extracts. Commun. Soil Sci. Plant Anal. 21:1519-1529.

Cipollini, D.F., and J. Bergelson. 2000. Environmental and developmental regulation of trypsin inhibitor activity in Brassica napus. J. Chem. Ecol. 26:1411-1422.

Cipollini, D.F., and J. Bergelson. 2001. Plant density and nutrient viability constrain constitutive and wound-induced expression of trypsin inhibitors in Brassica napus. J. Chem. Ecol. 27:593-610.

Cowgill, S.E., R.D. Bardgett, D.T. Kiezebrink, and H.J. Atkinson. 2002. The effect of transgenic nematode resistance on non-target organisms in the potato rhizosphere. J. Appl. Ecol. 39:915-923.

David, M.B., L.E. Gentry, D.A. Kovacic, and K.M. Smith. 1997. Nitrogen balance in and export from an agricultural watershed. J. Environ. Qual. 26:1038-1048.

Donegan, K.K., R.J. Seidler, V.J. Fieland, D.L. Schaller, C.J. Palm, L.M. Ganio, D.M. Cardwell, and Y. Steinberger. 1997. Decomposition of genetically engineered tobacco under field conditions: Persistence of the proteinase inhibitor I product and effects on soil microbial respiration and protozoa, nematode and microarthropod populations. J. Appl. Ecol. 34:767-777.

Duan, X., X. Li, Q. Xue, M. Abo-El-Saad, D. Xu, and R. Wu. 1996. Transgenic rice plants harboring an introduced proteinase inhibitor II gene are insect resistant. Nat. Biotechnol. 14:494-498.

Flores, S., D. Saxena, and G. Stotzky. 2005. Transgenic Bt plants decompose less in soil than non-Bt plants. Soil Biol. Biochem. 37: 1073-1082.

Geoffroy, P., M. Legrand, and B. Fritig. 1990. Isolation and characterization of a proteinaceous inhibitor of microbial proteinases induced during the hypersensitive reaction of tobacco to tobacco mosaic virus. Mol. Plant Microbe Interact. 3:327-333.

Green, T.R., and C.A. Ryan. 1992. Wound-induced proteinase inhibitor in plant leaves: A possible defense mechanism against insects. Science 175:776-777. 
Hankin, L., and D.E. Hill. 1978. Proportion of bacteria in agricultural soils able to produce degradative enzymes. Soil Sci. 126:40-43.

Harper, S.H.T., and J.M. Lynch. 1981. The kinetics of straw decomposition in relations to its potential to produce the phytotoxin acetic acid. J. Soil Sci. 32:627-637.

Hauck, R.D. 1982. Nitrogen-isotope-ratio analysis. p. 735-779. In A.L. Page et al. (ed.) Methods of soil analysis. Part 2. Chemical and microbiological properties. 2nd ed. Agron. Monogr. 9. ASA and SSSA, Madison, WI.

Haynes, R.J. 1999. Fate and recovery of ${ }^{15} \mathrm{~N}$-labeled fertilizer urea applied to winter wheat in spring in the Canterbury region of New Zealand. J. Agric Sci. 133:125-130.

Keeney, D.R., and T.H. DeLuca. 1993. Des Moines River nitrate in relation to watershed agricultural practices: 1945 versus 1980s. J. Environ. Qual. 22:267-272.

Klute, A. 1986. Water retention: Laboratory methods. p. 635-662. In A. Klute (ed.) Methods of soil analysis. Part 1. Soil physical properties. 2nd ed. Agron. Monogr. 9. ASA and SSSA, Madison, WI.

Koiwa, H., R.A. Bressan, and P.M. Hasegawa. 1997. Regulation of proteinase inhibitors and plant defense. Trends Plant Sci. 2:379-384.

Kumar, K., and K.M. Goh. 2000. Crop residues and management practices: Effects on soil quality, soil nitrogen dynamics, crop yield and nitrogen recovery. Adv. Agron. 68:197-319.

Kumar, K., and K.M. Goh. 2003. Nitrogen release from crop residues and organic amendments: Relationship to biochemical composition. Commun. Soil Sci. Plant Anal. 34:2441-2460.

Kumar, K., C.J. Rosen, and M.P. Russelle. 2004. A novel approach to regulate nitrogen mineralization in soil. p. 186-187. In D.J. Hatch et al. (ed.). Controlling nitrogen flows and losses. Wageningen Academic Publ., Wageningen, the Netherlands.

Loll, M.J., and J.M. Bollag. 1983. Protein transformation in soil. Adv. Agron. 36:351-382.

Lory, J.A., and M.P. Russelle. 1994. Evaluation of a diffusion method for preparing low-nitrogen samples for nitrogen-15 analysis. Soil Sci. Soc. Am. J. 58:1400-1404.

McLean, E.O. 1982. Soil pH and lime requirements. p. 199-224. In A.L. Page (ed.) Methods of soil analysis. Part 2. Chemical and microbiological properties. 2nd ed. ASA, Madison, WI

McManus, M.T., D.W.R. White, and P.G. McGregor. 1994. Accumulation of chymotrypsin inhibitor in transgenic tobacco can affect the growth of insect pests. Transgenic Res. 3:50-58.

Nelson, D.W., and L.E. Sommers. 1982. Total carbon, organic carbon and organic matter. p. 539-579. In A.L. Page (ed.) Methods of soil analysis. Part 2. Chemical and microbiological properties. 2nd ed. ASA, Madison, WI.

Ryan, C.A. 1981. Proteinase inhibitors. p. 351-370. In A. Marcus (ed.) The biochemistry of plants. Academic Press, New York.

Ryan, C.A. 1990. Protease inhibitors in plants: Genes for improving defenses against insects and pathogens. Annu. Rev. Phytopathol. 28:425-449.

SAS Institute. 1989. SAS/STAT users guide. Version 6. 4th ed. Vol. 1. SAS Inst., Cary, NC.

Theander, O., P. Aman, E. Westerlund, R. Andersson, and D. Pettersson. 1995. Total dietary fiber determined as neutral sugar residues, uronic acid residues, and Klason lignin (The Uppsala Method): Collaborative study. J. AOAC Int. 78:1030-1044.

Trinsoutrot, I., S. Recous, B. Bentz, M. Lineres, D. Cheneby, and B. Nicolardot. 2000. Biochemical quality of crop residues and nitrogen mineralization kinetics under nonlimiting nitrogen conditions. Soil Sci. Soc. Am. J. 64:918-926.

Whitmore, A.P., and E. Handayanto. 1997. Simulating the mineralization of $\mathrm{N}$ from crop residues in relation to residue quality. p. 349362. In G. Cadisch and K.E. Giller (ed.) Driven by nature-plant litter quality and decomposition. CABI, Wallingford, UK.

Van Dam, N., M. Horn, M. Mares, and I.T. Baldwin. 2001. Ontogeny constrains systemic protease inhibitor response in Nicotiana attenuata. J. Chem. Ecol. 27:547-568. 